\title{
Genetic Variability Analysis of Terrestrial Spathoglottis plicata Orchid Variants Based on RAPD Marker
}

\author{
Fay Della Prika Auvira ${ }^{1, *}$ Ixora Sartika Mercuriani ${ }^{2}$, Suyitno Aloysius ${ }^{2}$
}

\author{
${ }^{1}$ Bachelor student of Biology Study Program, Faculty of Mathemathic and Natural Science, Universitas Negeri \\ Yogyakarta \\ ${ }^{2}$ Academic staff in Biology Education Departement, Faculty of Mathemathic and Natural Science, Universitas \\ Negeri Yogyakarta \\ *Corresponding author. Email: faydella77@gmail.com
}

\begin{abstract}
The purpose to know the genetic variability of orchid variants Spathoglottis plicata based on molecular marker Random Amplified Polymorphic DNA (RAPD). DNA isolation carried out using TIANGEN Plant Genomic DNA kit. DNA sample was amplified using PCR-RAPD technique. Genetic variability were analyzed using GenAlex 6.1 software to obtain the percentage of polymorphism, genetic distance and principal coordinates. Moreover, NTSYS Version 2.02 Unweighted Pair-Group Method using Arithmetic Average (UPGAMA) was used to create cluster dendrogram based on similarity indeces of $S$. plicata orchid variants. The result showed that DNA polymorphism of $S$. plicata orchid variants is 53,28\%. Based on the Principal Coordinate Analysis (PCA), orchid variants $S$. plicata are spread in four quadrants in which the mutant variants on the opposite quadrant with wild type plants. Based on dendrogram, all orchid variants $S$. plicata are devided into 2 clusters of mutant plants which has a lower similarity index $(<0,64)$ compared to wild type $(>70)$ showing that mutant variants are potential to be new cultivars.
\end{abstract}

Keywords: Spathoglottis plicata, Genetic diversity, PCR-RAPD.

\section{INTRODUCTION}

Orchid (Orchidaceae) is a cosmopolitan plant that is spread all over the world. Indonesia is estimated to have 5000 species of orchids from a total of 25,000 species of orchids in the world [1]. The morphological diversity of orchids, especially from the characteristics of the shape and color of the flower, causes orchid favored by the community. Globally, orchids occupy the highest trade rank among other flowering plants. Orchid is widely used as an ornamental plant, medicine, and cut flower, this causes the demand for orchids continue to increase [2].

One genus of terrestrial orchids that grows in Indonesia is Spathoglottis. This orchid is used as an ornamental plant in Indonesia. Spathoglottis is less suitable for planting in pots because it has a relatively big habitus. In addition, long flower stems with small diameters make these orchids fall easily [3].
Genetic diversity of plant can be created through seed propagation using in vitro culture techniques, both propagation from seeds produced by selfing or crossing, as well as from mutagenesis. More than 40 variants of $S$. plicata orchid plants from in vitro seed culture from natural seeds and irradiated seeds were successfully obtained [4]. The orchid plants showed variations in the leaves morphology, the number of tillers, the size of the flowering stalks, and the color and size of the flowers. The variants of $S$. plicata orchid plants need to be characterized to find out the level of genetic variability as a selection effort to obtain potential plants into superior variants.

Genetic diversity can be seen from the level of DNA polymorphism. Polymorphism can result from in vitro seed culture, artificial crosses and from mutation induction which can be identified using molecular markers. One of the molecular markers that is widely used for characterization in some plants is RAPD. The RAPD is widely used because the cost 
is cheap, fast, easy to work on high polymorphism, and easy to obtain rndom primers needed to analyze the genome of all types of organism [5,6]. The PCRRAPD technique is a molecular characterization technique for amplifying genomic DNA using universal primers that target random sequences. The PCR-RAPD technique is a molecular characterization technique for amplifying genomic DNA using universal primers that target random sequences [7]. Variant of $S$. plicata plants without radiation and irradiated successfully obtained by Suyitno need to be characterized to determine the level of genetic variability among the variants.

\section{MATERIAL AND METHODS}

The research was molecular explorative observation used 17 plants of S. plicata variant resulted from in vitro seed culture that have survived by previous researchers [8]. Sample consist of $6 \mathrm{~S}$. plicata wild type variant and 11 mutant variant. The research was observed genetic variability of $S$. plicata variants based on the percentage of polymorphism, the separated of $S$. plicata variants based on genetic distance, and clustering of $S$. plicata variants based on dendogram cluster.

\subsection{DNA Isolation}

DNA was isolated using a TIANGEN Plant Genomic DNA kit. The isolated DNA was tested using electrophoresis and visualization methods using Documenter Gel (1012 Series Gel Documentation System). Concentration and purity of DNA sample was measured with TECAN Spark multicode microplate reader platform on the ratio of $\lambda 260 \mathrm{~nm}$ and $\lambda 280 \mathrm{~nm}$.

\subsection{PCR-RAPD analysis}

Genetic variability was analyzed besed on the PCR-RAPD technique. A total of 17 primers (OPA1, OPA 2, OPA 3, OPA 4, OPA 5, OPA 7, OPA 8, OPA 9 , OPA 10 , OPA 11 , OPA 12 , OPA 13 , OPA 14 , OPA 15, OPA 16, OPA 17, and OPA 18) were used for initially screening. For the screening, seven primers were selected based on the presence of polymorphic DNA (Table 1).

Table 1. Primers used for RAPD of S. plicata

\begin{tabular}{ccc}
\hline No & Primers & Sequence (5'-3') \\
\hline 1 & OPA-01 & CAGGCCCTTC \\
\hline
\end{tabular}

\begin{tabular}{ccc}
\hline 2 & OPA-02 & TGCCGAGCTG \\
3 & OPA-03 & AGTCAGCCAC \\
4 & OPA-04 & AATCGGGCTG \\
5 & OPA-09 & GGGTAACGCC \\
6 & OPA-13 & CAGCACCCAC \\
7 & OPA-18 & AGGTGACCGT \\
\hline
\end{tabular}

RAPD amplification was done in $15 \mu \mathrm{L}$ reaction volume containing 7,5 $\mu \mathrm{L}$ PCR mix (Promega Go Taq® Green Master Mix), $1 \mu \mathrm{L}$ primer $(10 \mu \mathrm{M}), 1$ $\mu \mathrm{L}$ DNA template (50x dilution), and 5,5 $\mu \mathrm{L}$ Nuclease Free Water. The PCR reaction started from pre-denaturation $\left(94^{\circ} \mathrm{C}, 3\right.$ minute) for one cycle; denaturation $\left(94^{\circ} \mathrm{C}, 30\right.$ second $)$, annealing $\left(29^{\circ} \mathrm{C}, 30\right.$ second), extension $\left(72^{\circ} \mathrm{C}, 2\right.$ minute), final extension $\left(72^{\circ} \mathrm{C}, 5\right.$ minute), for 40 cycles; holding $\left(4^{\circ} \mathrm{C}, \infty\right)$. PCR products were visualizaed with electrophoresis in $1 \%$ agarose gel containing $3 \mu \mathrm{L}$ florosafe, run on 50 volt for 45 minutes in $0,5 \mathrm{X}$ TBE (Tris Boric acid EDTA). DNA marker using Vivantis DNA ladder (1 $\mathrm{kb})$. The electrophoresis result were observed using Documentary Gel (1012 Series Gel Documentation System).

\subsection{Data Processing}

The PCR result was converted into binary data by giving scores. Score "1" if there was a DNA band and score " 0 " if there was no DNA band. The binary data was analyzed using GenAlex 6.1 software to obtain the percentage of polymorphism, genetic distance and principal coordinates. Moreover, NTSYS version 2.02 Unweighted Pair-group Method using Arithmetic Average (UPGAMA) method was used for clustering based on dendrogram of $S$. plicata variants.

\section{RESULT AND DISCUSSION}

\subsection{Morphology of S. plicata}

Variants of $S$. plicata mutant and wild type showed variations for several morphological features. Variations in characteristics can be seen from the length and width of leaves, plant height, and number of tillers as seen in plant samples, the result of the observations (Table 2). 


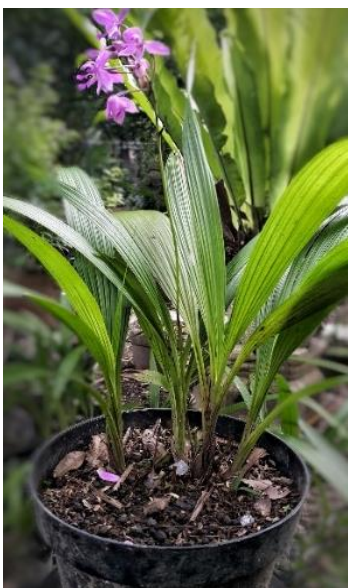

(a)

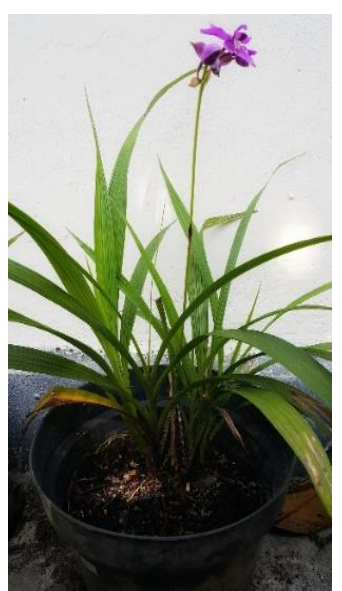

(b)
Figure 1. Habitus of Terrestrial Orchid S. plicata (a) wild type and (b) mutant mutagenesis. Genetic mutations have been shown to cause changes in morphological structure in the seeds of $S$. plicata mutants [8]. Mutations do not always have a significant impact on changes in plant phenotypes. This can occur due to several possibilities: 1) the type of mutation that occurs is a silent mutation. Silent mutations only change one nucleotide base pair without causing changes or changes in the type of amino acids produced or coded from the position of three codons. These mutations do not cause changes in the appearance of the phenotype, but can be detected genetically [9] 2) mutant plants have successfully recovered. Mutant $S$. plicata plants due to X-ray irradiation may be able to make a perfect recovery of genetic changes that occur so that morphologically is no different from wild type plants [10].

These variations can occur due to recombination of genes and or mutations due to the induced Table 2. Morphological Observation of $S$. plicata variants

\begin{tabular}{|l|c|c|c|c|c|c|}
\hline \multicolumn{1}{|c|}{ Sample } & $\begin{array}{c}\text { Shape of } \\
\text { Leaf }\end{array}$ & $\overline{\bar{X}}$ Length of leaf & $\bar{X}$ width of leaf & $\begin{array}{c}\text { Number of } \\
\text { leaf }\end{array}$ & $\bar{X}$ Plant height & $\begin{array}{c}\text { Number } \\
\text { of tillers }\end{array}$ \\
\hline WT $(\mathrm{n}=6)$ & Lanset & $35,30 \pm 13,47$ & $2,68 \pm 1,01$ & $16 \pm 8,87$ & $7,92 \pm 1,56$ & $5 \pm 2,43$ \\
\hline MT (n= 11) & Lanset & $28,13 \pm 11,17$ & $2,39 \pm 0,86$ & $12 \pm 5,46$ & $7,17 \pm 1,68$ & $4 \pm 1,61$ \\
\hline Average & Lanset & $31,71 \pm 12,13$ & $2,54 \pm 0,89$ & $14 \pm 6,95$ & $7,54 \pm 1,63$ & $5 \pm 1,87$ \\
\hline
\end{tabular}

Note: $\mathrm{WT}=$ wild type; $\mathrm{MT}=$ mutant

\subsection{Molecular analysis using PCR-RAPD}

The results visualization of the amplification from 17 S. plicata variant DNA samples using 7 RAPD primers produced polymorphic bands. The number of DNA fragments successfully amplified was 4-6 with a percentage of polymorphism was $60-100 \%$ (Table 3 ). These different fragments show the genetic variation of each sample.

Table 3. Polymorphic band of 17 S. plicata variants using 7 primers

\begin{tabular}{|c|c|c|c|c|c|}
\hline $\begin{array}{c}\text { Primer } \\
\text { s }\end{array}$ & Sequences (5'-3') & $\begin{array}{c}\text { No. of DNA } \\
\text { Bands }\end{array}$ & $\begin{array}{c}\text { No. of Polymorphic } \\
\text { DNA Bands }\end{array}$ & $\begin{array}{c}\text { No. of } \\
\text { Monomorphic DNA } \\
\text { Bands }\end{array}$ & $\begin{array}{c}\text { Polymorphis } \\
\text { m }(\%)\end{array}$ \\
\hline OPA-01 & CAGGCCCTTC & 4 & 4 & 0 & 100 \\
\hline OPA-02 & TGCCGAGCTG & 5 & 5 & 0 & 100 \\
\hline OPA-03 & AGTCAGCCAC & 4 & 4 & 0 & 100 \\
\hline OPA-04 & AATCGGGCTG & 6 & 6 & 0 & 100 \\
\hline OPA-09 & GGGTAACGCC & 5 & 5 & 0 & 100 \\
\hline OPA-13 & CAGCACCCAC & 5 & 5 & 2 & 100 \\
\hline OPA-18 & AGGTGACCGT & 5 & 3 & 0 & 60 \\
\hline
\end{tabular}

Based on analysis using the GenAlex 6.1 Program, the percentage of polymorphisms from 17 S. plicata variants was $53.28 \%$ (Table 4 ), which the polymorphisms percentage mutant variants $(59.02 \%)$ were higher than wild type variants $(47.54 \%)$. Nei's diversity and Shannon's index (Table 4 ) in the mutant 
variants that are higher than wild type variants confirm that the mutant variants have a higher level of genetic diversity compared to wild type plant variants.

Table 4. Percentage of polymorphic locus, Nei's Diversity, dan Shannon's Index

\begin{tabular}{|l|c|c|c|c|c|c|c|}
\hline \multirow{2}{*}{ Sample } & \multirow{2}{*}{$\mathbf{N}$} & $\begin{array}{l}\text { Polymorphic } \\
\text { locus (\%) }\end{array}$ & \multicolumn{5}{|c|}{ Diversity Based on Genetic Distance } \\
\cline { 4 - 8 } & & $\mathbf{N a}$ & $\mathbf{N e}$ & $\mathbf{I}$ & $\mathbf{h}$ & uh \\
\hline WT & 6 & 47,54 & $1.07 \pm 0,12$ & $1.34 \pm 0,05$ & $0.28 \pm 0,03$ & $0.19 \pm 0,03$ & $0.23 \pm 0,03$ \\
\hline Mutant & 11 & 59,02 & $1.33 \pm 0,11$ & $1.42 \pm 0,05$ & $0.34 \pm 0,03$ & $0.23 \pm 0,03$ & $0.26 \pm 0,03$ \\
\hline Rata-rata & 53,28 & $1.20 \pm 0,08$ & $1.38 \pm 0,04$ & $0.31 \pm 0,03$ & $0.21 \pm 0,02$ & $0.24 \pm 0,02$ \\
\hline
\end{tabular}

$\mathrm{Na}=$ No. of different allels

$\mathrm{h}=$ Nei's Diversity

$\mathrm{uh}=$ unbiased diversity

The furthest genetic distance (38) was V11 (mutant) and V6 (wild type) (Table 5). The genetic distance indicate that the mutant variant (V11, V14 and V10) have a far kinship with wild type plants. The Principal Coordinates Analysis (PCA) result showed that the position of $S$. plicata mutants variants are on quadrant III and quadrant IV increasingly going further away from wild type variants (Figure 2). Dendrogram categorized $17 \mathrm{~S}$. plicata variants into two main groups with 0,6 similarity coefficient. The first group consisted of wild type variants (V1-V6) and the second group consisted of mutant variants (V7-V17). Mutant variants have lower similarities compared to wild type variant. The mutant variant had $<64 \%$ similarity, while the wild type variant had $>70 \%$ similarity. This shows that the variant of $S$. plicata mutant are potential to be a new cultivar.
Genetic variations in wild type variants are likely due to the multiplication of wild type variants derived from generative reproduction (seeds) cultured in vitro. In vitro culture can induce genetic changes. It is this genetic change that causes genetic diversity. The genetic diversity of a plant from in vitro culture is known as somaclonal variation. Somaclonal variations can be caused by several factors such as the use of growth regulators, especially high concentrations of auxins and cytokinins, composition of the medium used during the in vitro culture process, the duration of the culture process, and the stress conditions in vitro [11]. The percentage of polymorphism of the mutant variant that is greater than that of the wild type variants indicates that there may have been a change in DNA sequence in the mutant $S$. plicata variant due to the influence of $\mathrm{X}$ ray irradiation given by previous researchers.

Table 5. The genetic distance of 17 S. plicata variants

\begin{tabular}{|c|c|c|c|c|c|c|c|c|c|c|c|c|c|c|c|c|c|}
\hline & V1 & V2 & V3 & V4 & V5 & V6 & V7 & V8 & V9 & V10 & V11 & V12 & V13 & V14 & V15 & V16 & V17 \\
\hline V1 & 0 & & & & & & & & & & & & & & & & \\
\hline V2 & 17 & 0 & & & & & & & & & & & & & & & \\
\hline V4 & 13 & 16 & 14 & 0 & & & & & & & & & & & & & \\
\hline V5 & 17 & 16 & 16 & 12 & 0 & & & & & & & & & & & & \\
\hline V8 & 30 & 25 & 25 & 31 & 33 & 35 & 5 & 0 & & & & & & & & & \\
\hline V9 & 31 & 28 & 26 & 32 & 32 & 34 & 10 & 9 & 0 & & & & & & & & \\
\hline V10 & 34 & 29 & 27 & 35 & 35 & 37 & 7 & 4 & 7 & 0 & & & & & & & \\
\hline V11 & 33 & 30 & 26 & 34 & 34 & 38 & 8 & 9 & 12 & 9 & 0 & & & & & & \\
\hline V12 & 29 & 26 & 26 & 32 & 28 & 26 & 20 & 23 & 24 & 23 & 22 & 0 & & & & & \\
\hline V16 & 26 & 25 & 27 & 31 & 31 & 29 & 19 & 22 & 23 & 24 & 21 & 7 & 7 & 7 & 8 & 0 & \\
\hline V17 & 28 & 27 & 25 & 31 & 29 & 27 & 23 & 24 & 25 & 26 & 25 & 3 & 7 & 7 & 6 & 8 & 0 \\
\hline
\end{tabular}




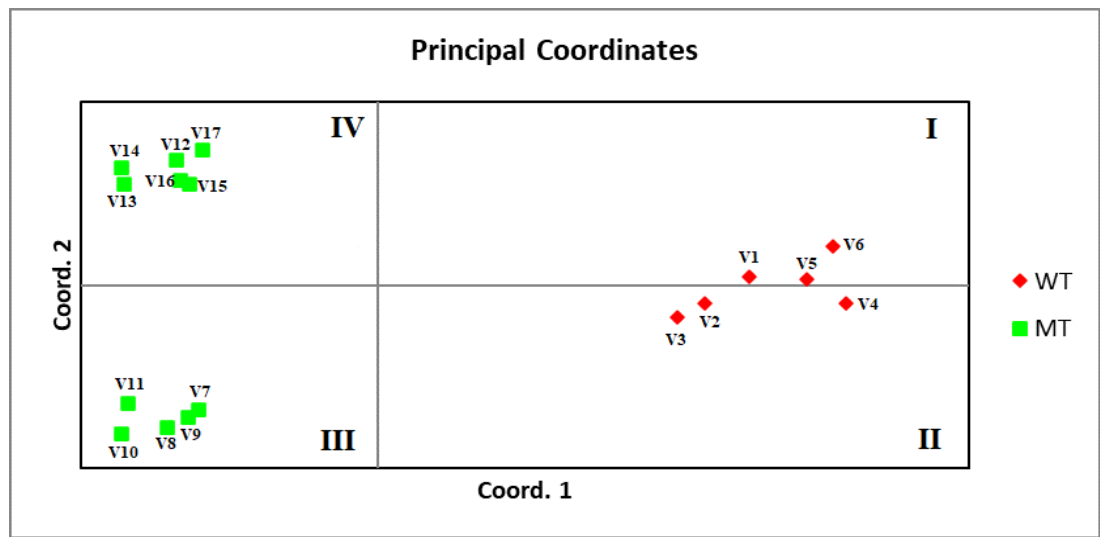

Figure 2. Principal coordinates of molecular of $17 \mathrm{~S}$. plicata variants. WT= wild type, $\mathrm{MT}=$ mutant.

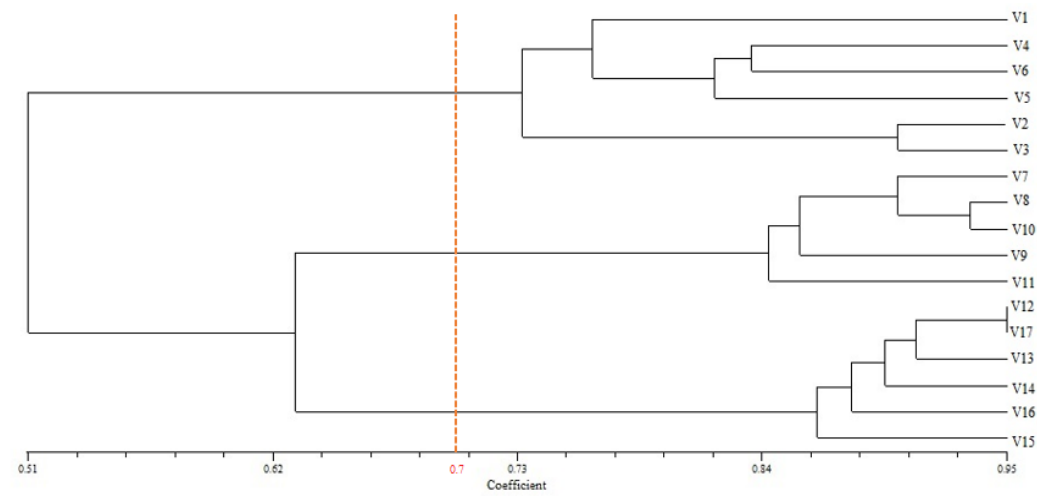

Figure 3. Dendrogram of 17 S. plicata variants based on genetic distance.

\section{CONCLUSION}

The percentage of polymorphism of DNA $S$. plicata variants based on RAPD marker was 53,28\%. $S$. plicata variants based on genetic distance are spread in four quadrants in which the mutant variants is in the opposite quadrant with wild type variants. Mutant variant has a lower similarity index $(<0,64)$ compared to wild type $(>0,70)$ showing that mutant variants are potential to be new cultivars.

\section{ACKNOWLEDGMENTS}

The research was supported by Daftar Isian Pelaksanaan Anggaran (DIPA) Faculty of Mathematics and Natural Science, Universitas Negeri Yogyakarta.

\section{REFERENCES}

[1] Irawati. Konservasi Anggrek Spesies di Indonesia. Prosiding Seminar Anggrek Indonesia 2002. Yogyakarta, 46-56.
[2] Hinsley, A., H.J. De Boer, M.F. Fay, S.W. Gale, L.M. Gardiner, R.S. Gunasekara, P. Kumar, S. Masters, D. Metusala, D.L. Roberts, S. Veldman, S. Wong, \& J.Phelps. A review of the trade in orchids and its impications for conservation. Botanical Journal of the Linnean Society, 2018, 186, 435-455

[3] Bety, Y.A., Y. Sulyo, A. Muharam, \& F. Rahmawati. Perbaikan varietas anggrek Spathoglottis melalui hibridisasi. Laporan Proyek Balai Penelitian Tanaman Hias, Segunung, 2001,7.

[4] Suyitno Aloysius. Variasi morfologis, fisiologis, dan molekular tanaman anggrek spathoglottis plicata blume hasil irradiasi sinar-x. [Disertasi], tidak diterbitkan, Universitas Gadjah Mada, Yogyakarta. 2017.

[5] Tingey, S.V., J.A. Rafalski, \& M.K. Hanafey. Genetic analysis with RAPD markers. In: Coruzzi, C. and P. Puidormenech (eds.). Plant 
Molecular Biology. Belin: Springer-Verlag.1994. pp 492

[6] Poerba, Yuyu Sari dan Diyah Martanti. Keragaman Genetik berdasarkan Marka Random Amplified Polymorphic DNA pada Amorphophallus muelleri Blume di Jawa. Jurnal Biodiversitas,2008, 9 (4):245-249

[7] Williams, J. G., Kubelik, A. R., Livak, K. J., Rafalski, J. A., \& Tingey, S. V. DNA polymorphisms amplified by arbitrary primers are useful as genetic markers. Nucleic acids research,1990, 18(22): 6531-6535

[8] Suyitno Aloysius, Aziz Purwantoro, Kumala Dewi, \& Endang Semiarti. Improvement of genetic variability in seedlings of Spathoglottis plicata orchids through X-ray irradiation. Biodiversitas, 2017,Vol 18 (1): 20-27

[9] Sastrosumarjo, S., Yudiwanti, S.I. Aisyah, S. Sujiprihati, M. Syukur, R. Yunianti. Sitogenetika Tanaman. Bagian Genetika dan Pemuliaan Tanaman. Departemen Agronomi dan Hortikultura. Institut Pertanian Bogor. Bogor. 2006.

[10] Suyitno Aloysius, Aziz Purwantoro, Kumala Dewi, \& Endang Semiarti. Phenotypic variation and genetic alteration of Spathoglottis plicata resulted from in vitro cultured seed irradiated with X-Ray. Biodiveersitas, 2018, Vol 10 (5): 16421648

[11] Taji, A., Prakash, N., \& Lakshmanan, P. In vitro plant breeding. food products Press. 2005, pp 9495 